Article

\title{
Effects of Catalysts and Membranes on the Performance of Membrane Reactors in Steam Reforming of Ethanol at Moderate Temperature
}

\author{
Manabu Miyamoto ${ }^{1, *}$, Yuki Yoshikawa ${ }^{2}$, Yasunori Oumi ${ }^{3}$, Shin-ichi Yamaura ${ }^{4}$ \\ and Shigeyuki Uemiya ${ }^{1, *}$ \\ 1 Department of Chemistry and Biomolecular Science, Gifu University, 1-1 Yanagido Gifu 501-1193, Japan \\ 2 Department of Materials Science and Technology, Gifu University, 1-1 Yanagido Gifu 501-1193, Japan; \\ yukiy0115@yahoo.co.jp \\ 3 Division of Instrument Analysis, Life Science Research Center, Gifu University, 1-1 Yanagido Gifu 501-1193, \\ Japan; oumi@gifu-u.ac.jp \\ 4 Institute for Materials Research, Tohoku University, 2-1-1 Katahira, Aoba, Sendai 980-8577, Japan; \\ yamaura@imr.tohoku.ac.jp \\ * Correspondence: m_miya@gifu-u.ac.jp (M.M.); uemiya@gifu-u.ac.jp (S.U.); Tel./Fax: +81-58-293-2588 (M.M.); \\ +81-58-293-2583 (S.U.)
}

Academic Editors: Angelo Basile and Catherine Charcosset

Received: 20 April 2016; Accepted: 26 May 2016; Published: 3 June 2016

\begin{abstract}
Steam reforming of ethanol in the membrane reactor using the $\mathrm{Pd}_{77} \mathrm{Ag}_{23}$ membrane was evaluated in $\mathrm{Ni} / \mathrm{CeO}_{2}$ and $\mathrm{Co} / \mathrm{CeO}_{2}$ at atmospheric pressure. At $673 \mathrm{~K}$, the $\mathrm{H}_{2}$ yield in the $\mathrm{Pd}_{77} \mathrm{Ag}_{23}$ membrane reactor over $\mathrm{Co} / \mathrm{CeO}_{2}$ was found to be higher than that over $\mathrm{Ni} / \mathrm{CeO}_{2}$, although the $\mathrm{H}_{2}$ yield over $\mathrm{Ni} / \mathrm{CeO}_{2}$ exceeded that over $\mathrm{Co} / \mathrm{CeO}_{2}$ at $773 \mathrm{~K}$. This difference was owing to their reaction mechanism. At $773 \mathrm{~K}$, the effect of $\mathrm{H}_{2}$ removal could be understood as the equilibrium shift. In contrast, the $\mathrm{H}_{2}$ removal kinetically inhibited the reverse methane steam reforming at low temperature. Thus, the low methane-forming reaction rate of $\mathrm{Co} / \mathrm{CeO}_{2}$ was favorable at $673 \mathrm{~K}$. The addition of a trace amount of $\mathrm{Ru}$ increased the $\mathrm{H}_{2}$ yield effectively in the membrane reactor, indicating that a reverse $\mathrm{H}_{2}$ spill over mechanism of Ru would enhance the kinetical effect of $\mathrm{H}_{2}$ separation. Finally, the effect of membrane performance on the reactor performance by using amorphous alloy membranes with different compositions was evaluated. The $\mathrm{H}_{2}$ yield was set in the order of $\mathrm{H}_{2}$ permeation flux regardless of the membrane composition.
\end{abstract}

Keywords: amorphous alloy membranes; membrane reactor; steam reforming; ethanol

\section{Introduction}

Hydrogen has been considered as one of the most promising clean energies because its combustion emits only water. Most of the hydrogen produced currently comes from catalytic steam reforming of natural gas [1]. Steam reforming of natural gas is a mature technology as a practical application, and it has been employed for hydrogen production from various hydrogen sources such as liquefied petroleum gas [2,3] iso-octane [4] and kerosene [5-8]. Considering the sustainable society, hydrogen production from fossil fuels is undesirable, and it would shift to renewable sources such as biomass-derived fuels. In particular, biomass-derived liquid fuels are preferable to direct hydrogen storage for on-site hydrogen production owing to their convenience for storage and transport. Among biomass-derived liquid fuels, bioethanol has been frequently studied for hydrogen production because it is easy to handle and distribute and it is readily available [9]. This process can be realized under far milder conditions than those of methane steam reforming. Therefore, the steam reforming of bioethanol is more attractive from practical and environmental view points. In the last decade, 
many researchers have made efforts to develop catalysts for steam reforming of ethanol aimed at hydrogen production [10-12]. Noble metal catalysts ( $\mathrm{Pd}, \mathrm{Pt}, \mathrm{Rh}, \mathrm{Ru}$ ) exhibited high catalytic activity and stability [13-15]. Inexpensive catalysts involving $\mathrm{Ni}$ or Co have been also proposed as appropriate candidates in terms of activity and selectivity [16-19]. However, the process efficiency for hydrogen production must be further improved when hydrogen can be used as an energy source for fuel cells. Additionally, extremely purified hydrogen is required for the low-temperature fuel cells such as proton exchange membrane fuel cells because of irreversible catalyst poisoning even by a trace amount of CO $[20,21]$.

Membrane reactors using hydrogen selective membranes such as $\mathrm{Pd}$ and $\mathrm{Pd}$ alloy membranes are expected to be one of the promising technologies to achieve high hydrogen production efficiency with high hydrogen purity, because extremely purified hydrogen can be obtained in one step with high hydrogen yield over the thermodynamic equilibrium, owing to simultaneous hydrogen separation from the reaction zone. Therefore, hydrogen production from several fuels using membrane reactors have been extensively studied so far [22-24]. Recently, steam reforming of ethanol has been also investigated by several research groups [25-30]. Basile and co-workers systematically investigated the performance of a membrane reactor using a Pd-Ag membrane packed with $\mathrm{Co} / \mathrm{Al}_{2} \mathrm{O}_{3}$ catalysts in steam reforming of ethanol [25,26], and achieved $100 \%$ ethanol conversion, $95.0 \% \mathrm{CO}$-free hydrogen recovery and up to $60 \% \mathrm{CO}$-free hydrogen yield at $673 \mathrm{~K}$ and 3.0 bar. They also investigated the effect of by-products such as acetic acid and glycerol as well [27]. Llorca and co-workers investigated the effect of reactor configurations over Co talc [28] and Co hydrotalcite [29] and demonstrated the higher performance of the catalytic membrane reactors using Pd-Ag membranes compared to the staged membrane reactor, where the catalyst has been placed in-series with the membrane. The enhancement of reactor performance by simultaneous hydrogen separation was also reported by Oyama's group. They evaluated the effect of membrane performance on the reactor performance by comparison between $\mathrm{Pd}-\mathrm{Cu}$ and $\mathrm{SiO}_{2}-\mathrm{Al}_{2} \mathrm{O}_{3}$ membranes and found that both permeance and selectivity had a favorable effect on steam reforming of ethanol in membrane reactors [30]. These studies clearly demonstrated the positive effect of membrane reactors in steam reforming of ethanol. However, there are only a few comparison studies on the effect of catalysts and membranes, and, in this study, we evaluated the Pd-Ag membrane reactor packed with $\mathrm{Ni}$ or Co based catalysts and then carried out the comparison study of the effect of membranes on the reactor performance using $\mathrm{Pd}-\mathrm{Ag}$ and amorphous alloy membranes.

\section{Experimental Section}

\subsection{Preparation of Catalysts}

For the experiment, $15 \mathrm{wt} \% \mathrm{Ni} / \mathrm{CeO}_{2}$ and $15 \mathrm{wt} \% \mathrm{Co} / \mathrm{CeO}_{2}$ were prepared as the literature reported [31]. For $\mathrm{Ni} / \mathrm{CeO}_{2}$, nickel acetate tetrahydrate was dissolved in deionized water and stirred at $343 \mathrm{~K}$. After adding $\mathrm{CeO}_{2}$ (mean particle size: $1 \mu \mathrm{m}$ ), the $\mathrm{pH}$ was adjusted to 9 by adding $0.25 \mathrm{M}$ $\mathrm{Na}_{2} \mathrm{CO}_{3}$ aqueous solution. Then, the water was slowly vaporized at $373 \mathrm{~K}$ to obtain the precipitation, and the precipitation was calcined at $673 \mathrm{~K}$ for $5 \mathrm{~h}$. For preparation of $\mathrm{Co} / \mathrm{CeO}_{2}$, the preparation procedure was the same to that for $\mathrm{Ni} / \mathrm{CeO}_{2}$. Cobalt acetate tetrahydrate was used as the cobalt source.

Preparation of $\mathrm{Ru}-\mathrm{Co} / \mathrm{CeO}_{2}$ and $\mathrm{Pd}-\mathrm{Co} / \mathrm{CeO}_{2}$ was as follows. Ruthenium chloride or palladium chloride was dissolved in deionized water and stirred. Then, $\mathrm{Co} / \mathrm{CeO}_{2}$ was added in the solution $(\mathrm{M} / \mathrm{Co}=0.003 w / w, \mathrm{M}=\mathrm{Ru}$ or $\mathrm{Pd})$ and the solvent was slowly vaporized at $373 \mathrm{~K}$. The obtained solid material was calcinced at $823 \mathrm{~K}$ under an $\mathrm{N}_{2}$ flow for $5 \mathrm{~h}$.

\subsection{Preparation of Amorphous Alloy Membranes}

Alloy ingots were prepared by arc melting a mixture of pure metals with the appropriate composition. After remelting the alloys several times to make better homogeneity, a ribbon sample was obtained by a single roller melt-spinning method. Both surfaces of the ribbon were polished and 
sputtered with Pd coating with the thickness of approximately $100 \mathrm{~nm}$. The appearance of obtained membrane was shown in Figure 1.

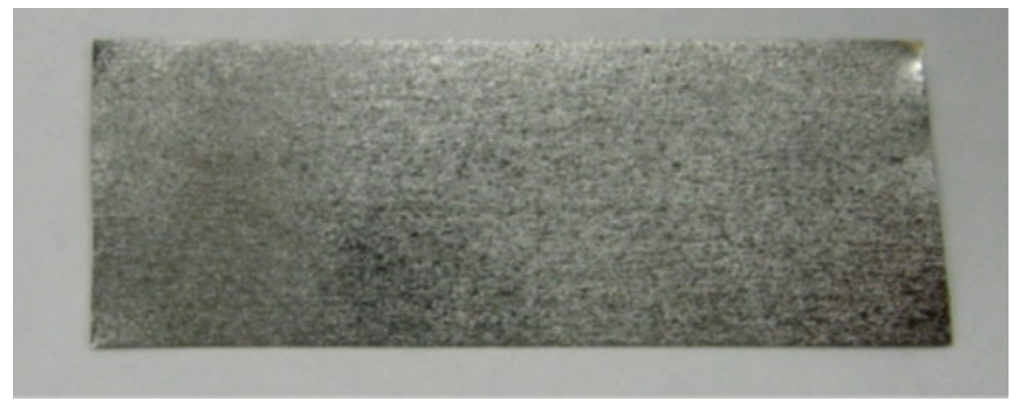

Figure 1. Image of amorphous alloy membrane prepared by single roller melting-spinning method.

\subsection{Characterization}

Hydrogen permeation tests. The amorphous alloy membranes (size: $10 \mathrm{~mm} \times 10 \mathrm{~mm}$ ) were placed in the separator sealed by $\mathrm{Cu}$ gaskets. The membrane was pre-heated in vacuum up to $673 \mathrm{~K}$. Then, the membrane was cooled down to $623 \mathrm{~K}$. After keeping the membrane at $673 \mathrm{~K}_{,} \mathrm{H}_{2}$ was introduced at the appropriate pressure $(0.05,0.10$ and $0.15 \mathrm{MPa}-\mathrm{G})$. The flow rate at the permeation side was measured by the soup-film flow meter.

Catalytic tests. The steam reforming of ethanol was carried out in a conventional reactor and membrane reactor. In the conventional reactor, the $10 \mathrm{~g}$ of catalysts was placed in the reactor and heated to $773 \mathrm{~K}$ under an $\mathrm{N}_{2}$ flow. Then, the catalyst was reduced under an $\mathrm{H}_{2}$ flow at $773 \mathrm{~K} \mathrm{for} 1 \mathrm{~h}$. After controlling the reaction temperature $(623-773 \mathrm{~K})$, a mixture of water and ethanol with the steam to carbon ratio $(S / C)$ of two was fed into the reactor at atmospheric pressure. The products were analyzed with a GC-8A gas chromatograph (Shimadzu Corporation, Kyoto, Japan) and the outlet gas flow rate was measured by the soup-film flow meter.

In the membrane reactor, the catalysts and membrane were placed in the reactor. The reactor was heated to $773 \mathrm{~K}$ under an $\mathrm{N}_{2}$ flow, and catalyst was reduced for $1 \mathrm{~h}$ under an $\mathrm{H}_{2}$ flow. The Ar sweep gas was used at the permeation side in the reactor. A mixture of water and ethanol with the $S / C$ of two was fed into the reactor after staying at the reaction temperature. The total pressure at both feed and permeate sides was maintained at atmospheric pressure. The gas composition in the retentate and permeate side was analyzed with the gas chromatograph and the outlet gas flow rate in both sides was measured by the soup flow meter. $\mathrm{A} \mathrm{Pd}_{77} \mathrm{Ag}_{23}$ membrane (thickness: $20 \mu \mathrm{m}$, purchased from Tanaka Kikinzoku Kogyo K.K., Tokyo, Japan) was used as reference.

The conversion of ethanol to $\mathrm{C}_{1}$ products and $\mathrm{H}_{2}$ yield was calculated as follows:

$$
\text { Conversion of ethanol to } \mathrm{C}_{1} \text { products }=\frac{\text { flow rate of } \mathrm{CO}, \mathrm{CO}_{2} \text { and } \mathrm{CH}_{4} \text { in products }}{\text { feed rate of ethanol } \times 2},
$$

$$
\mathrm{H}_{2} \text { yield }=\frac{\text { flow rate of } \mathrm{H}_{2} \text { in products }}{\text { feed rate of ethanol } \times 6} \text {. }
$$

Additionally, we defined $\mathrm{H}_{2}$ removal ratio as follows to compare the membrane reactor performance:

$$
H_{2} \text { removal ratio }[\%]=\frac{H_{2} \text { permeation flow rate }[\mathrm{mol} / \mathrm{min}]}{\text { Theoritical } \mathrm{H}_{2} \text { production rate }[\mathrm{mol} / \mathrm{min}]} \times 100 \text {. }
$$




\section{Results and Discussion}

\subsection{Membrane Reactor Performance Using $\mathrm{Pd}_{77} \mathrm{Ag}_{23}$ Membrane with $\mathrm{Co} / \mathrm{CeO}_{2}$ and $\mathrm{Ni} / \mathrm{CeO}_{2}$ Catalysts}

Figure 2 shows the comparison of reactor performance of the conventional reactor and membrane reactor with the $\mathrm{Pd}$ membrane over $\mathrm{Co} / \mathrm{CeO}_{2}$ and $\mathrm{Ni} / \mathrm{CeO}_{2}$ catalysts. In the conventional reactor, $\mathrm{Ni} / \mathrm{CeO}_{2}$ exhibited higher conversion of ethanol to $\mathrm{C}_{1}$ products compared to $\mathrm{Co} / \mathrm{CeO}_{2}$ catalysts. However, the $\mathrm{H}_{2}$ yield over $\mathrm{Ni} / \mathrm{CeO}_{2}$ did not exceed those over $\mathrm{Co} / \mathrm{CeO}_{2}$ at the reaction temperatures from 673 to $773 \mathrm{~K}$. Regardless of catalysts, the membrane reactor exhibited higher conversion and $\mathrm{H}_{2}$ yield than the conventional reactor, but the influence of $\mathrm{Pd}_{77} \mathrm{Ag}_{23}$ membrane was different between the catalysts. The increase in conversion of ethanol to $\mathrm{C}_{1}$ products over $\mathrm{Ni} / \mathrm{CeO}_{2}$ by the $\mathrm{Pd}_{77} \mathrm{Ag}_{23}$ membrane was much higher than those over $\mathrm{Co} / \mathrm{CeO}_{2}$ catalysts, and it achieved more than $90 \%$ at $723 \mathrm{~K}$, whereas the conversion was only $65 \%$ at $773 \mathrm{~K}$ over $\mathrm{Co} / \mathrm{CeO}_{2}$. The $\mathrm{H}_{2}$ yield over $\mathrm{Co} / \mathrm{CeO}_{2}$ increased by almost $13 \%$ regardless of temperature, e.g., $44.4 \%$ and $57.8 \%$ at $773 \mathrm{~K}$ for the conventional reactor and membrane reactor, respectively. In contrast, it was found that the increase in $\mathrm{H}_{2}$ yield over $\mathrm{Ni} / \mathrm{CeO}_{2}$ was significantly improved with an increase in the reaction temperature (from $27.4 \%$ at $673 \mathrm{~K}$ to $64.5 \%$ at $773 \mathrm{~K}$ ). These results indicate that the influence of $\mathrm{H}_{2}$ removal from the reaction zone through the $\mathrm{Pd}_{77} \mathrm{Ag}_{23}$ membrane was higher over $\mathrm{Ni} / \mathrm{CeO}_{2}$ than $\mathrm{Co} / \mathrm{CeO}_{2}$ at the high reaction temperature. However, $\mathrm{Co} / \mathrm{CeO}_{2}$ was suitable for the membrane reactor at low reaction temperature. Figure 3 shows the selectivity of $\mathrm{C}_{1}$ products. For $\mathrm{Ni} / \mathrm{CeO}_{2}$, the main product at $673 \mathrm{~K}$ was methane $(58.1 \%)$ and a slight decrease in the methane selectivity was observed $(51.1 \%)$ in the membrane reactor at this reaction temperature. The methane selectivity was slightly decreased to $41.4 \%$ at $773 \mathrm{~K}$ in the conventional reactor, and the simultaneous $\mathrm{H}_{2}$ removal by $\mathrm{Pd}_{77} \mathrm{Ag}_{23}$ membrane greatly enhanced the $\mathrm{CO}_{2}$ selectivity with decreasing of the methane selectivity. Furthermore, the membrane reactor showed lower methane selectivity of $25.9 \%$ at $773 \mathrm{~K}$. For $\mathrm{Co} / \mathrm{CeO}_{2}$, the main product in the conventional reactor was $\mathrm{CO}_{2}$ regardless of the reaction temperature and the methane selectivity was very low $(28.8 \%$ and $18.9 \%$ at $673 \mathrm{~K}$ and $773 \mathrm{~K}$, respectively) compared to $\mathrm{Ni} / \mathrm{CeO}_{2}$. In the membrane reactor, the methane selectivity was decreased, and it was noting that the decrease in methane selectivity was much higher at $673 \mathrm{~K}$ than $773 \mathrm{~K}$ in $\mathrm{Co} / \mathrm{CeO}_{2}$. Torres et al. reported the difference in reaction path in the steam reforming of ethanol [16], and their reaction scheme is summarized in Scheme 1. In the literature, at high reaction temperature, the steam reforming of ethanol was dominant over both $\mathrm{Ni}$ and Co catalysts. However, the reaction path was largely different at the moderated reaction temperature between $\mathrm{Ni}$ and Co catalysts. The initial reaction was ethanol dehydrogenation to acetaldehyde over both catalysts. The product selectivity approached the thermodynamic equilibrium in Ni catalysts because of the methane-forming reaction such as ethanol cracking, acetaldehyde decarbonilation and the reverse methane steam reforming. On the other hand, the Co catalysts did not promote such methane-forming reactions and the steam reforming of acetaldehyde was preferably occurred. Considering their reaction scheme, the highly increased $\mathrm{H}_{2}$ yield over $\mathrm{Ni} / \mathrm{CeO}_{2}$ in the membrane reactor at $773 \mathrm{~K}$ was due to the shift of equilibrium by simultaneous $\mathrm{H}_{2}$ removal through the $\mathrm{Pd}_{77} \mathrm{Ag}_{23}$ membrane. However, at $673 \mathrm{~K}$, it was easy for $\mathrm{Ni} / \mathrm{CeO}_{2}$ to produce methane and the methane steam reforming would be hardly promoted once methane produced even when $\mathrm{H}_{2}$ was selectively removed from the reaction zone because the methane steam reforming is kinetically and thermodynamically unfavorable at low temperature. Therefore, the low $\mathrm{H}_{2}$ yield was owing to the preferential production of methane in both conventional and membrane reactors at low temperature. In contrast, because of the low reaction rate of methane-forming reactions in $\mathrm{Co} / \mathrm{CeO}_{2}$, the $\mathrm{Pd}_{77} \mathrm{Ag}_{23}$ membrane could remove produced $\mathrm{H}_{2}$ from the reaction zone before $\mathrm{H}_{2}$ was consumed by the reverse methane steam reforming. This means the selective $\mathrm{H}_{2}$ removal through $\mathrm{Pd}_{77} \mathrm{Ag}_{23}$ membrane kinetically inhibited the methane production, resulting in high $\mathrm{H}_{2}$ yield at low reaction temperature. Indeed, Seelam et al. reported $\mathrm{Co} / \mathrm{Al}_{2} \mathrm{O}_{2}$ that showed high membrane performance at $673 \mathrm{~K}$ compared to $\mathrm{Ni} / \mathrm{ZrO}_{2}$ because of high methane selectivity in $\mathrm{Ni} / \mathrm{ZrO}_{2}$ [27], which is consistent with our experimental results. 

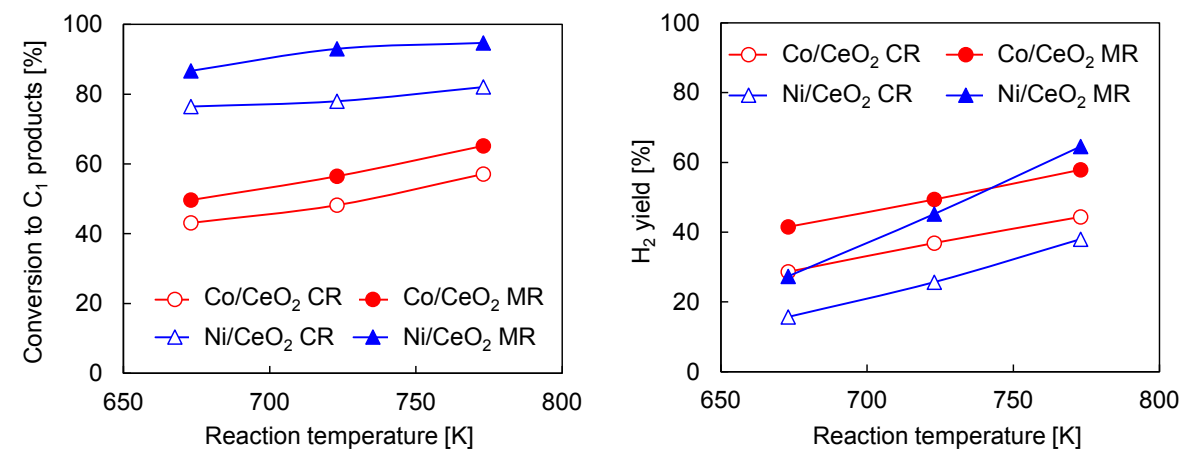

Figure 2. Conversion of ethanol to $\mathrm{C}_{1}$ products and $\mathrm{H}_{2}$ yield over $\mathrm{Co} / \mathrm{CeO}_{2}$ and $\mathrm{Ni} / \mathrm{CeO}_{2}$ catalysts in steam reforming of ethanol. CR: conventional reactor, MR: membrane reactor, $W / F: 1.0 \times 10^{4} \mathrm{~g}$-cat min/C-mol. $S / C=2$. Membrane: $\mathrm{Pd}_{77} \mathrm{Ag}_{23}$, Sweep Ar flow rate: $500 \mathrm{~mL} / \mathrm{min}$.
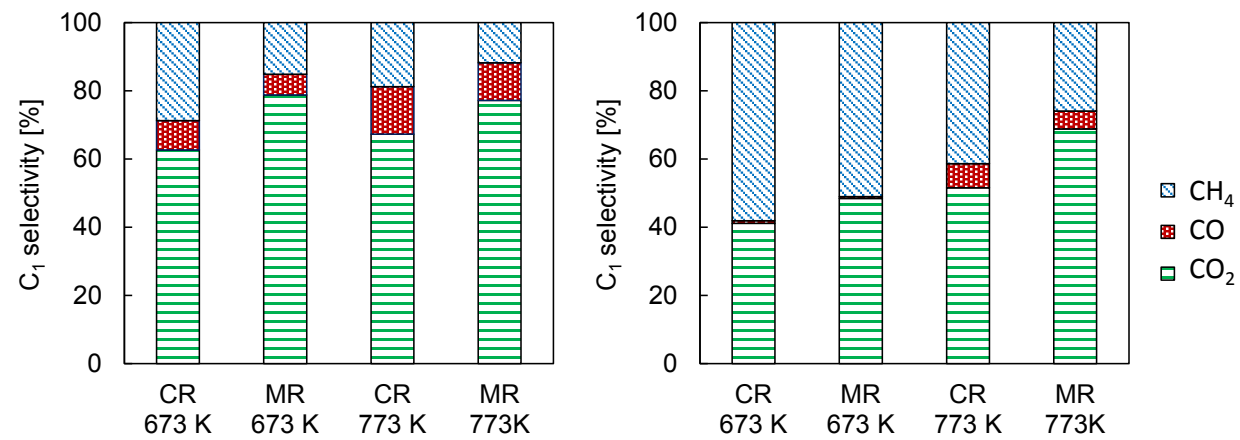

Figure 3. Selectivity of $\mathrm{C}_{1}$ products over $\mathrm{Co} / \mathrm{CeO}_{2}$ (left) and $\mathrm{Ni} / \mathrm{CeO}_{2}$ (right) catalysts in steam reforming of ethanol. CR: conventional reactor, MR: membrane reactor, W/F: $1.0 \times 10^{4} \mathrm{~g}$-cat min/C-mol. $S / C=2$. Membrane: $\mathrm{Pd}_{77} \mathrm{Ag}_{23}$, Sweep Ar flow rate: $500 \mathrm{~mL} / \mathrm{min}$.

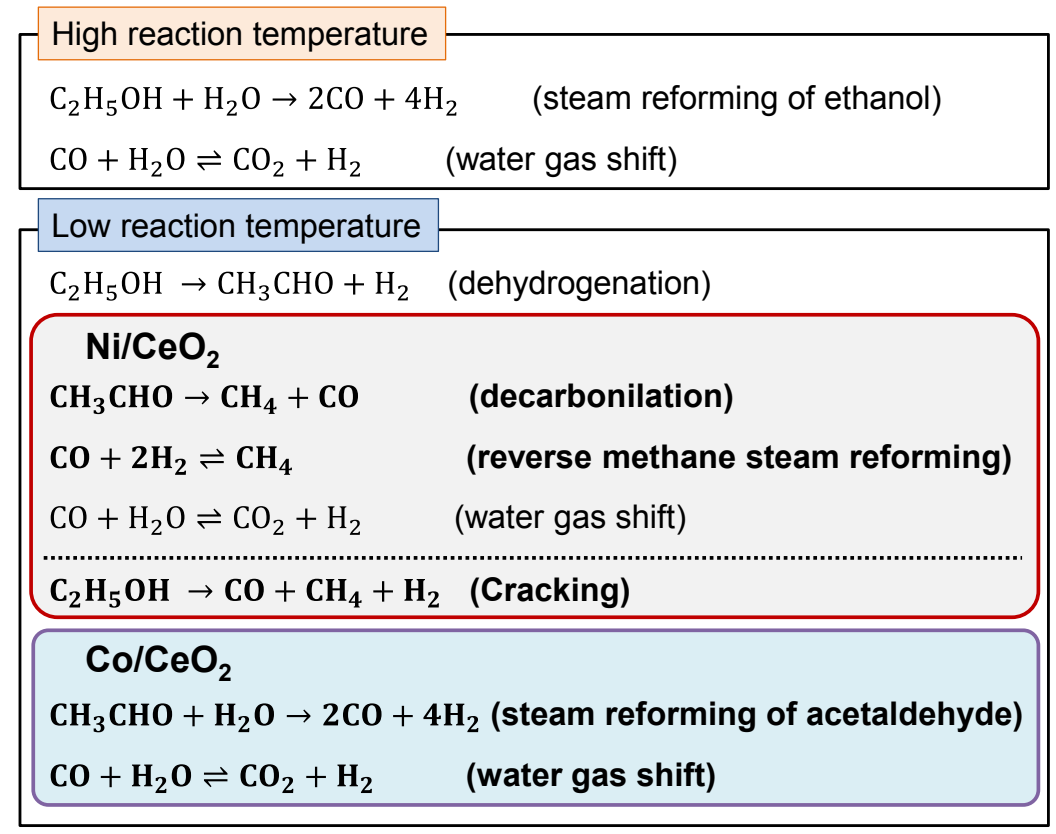

Scheme 1. Difference in reaction path over $\mathrm{Ni}$ and Co catalysts in steam reforming of ethanol [16]. 


\subsection{Catalyst Development for Improving the Membrane Reactor Performance}

Comparing $\mathrm{Co} / \mathrm{CeO}_{2}$ and $\mathrm{Ni} / \mathrm{CeO}_{2}, \mathrm{Co} / \mathrm{CeO}_{2}$ was preferable to $\mathrm{Ni} / \mathrm{CeO}_{2}$ for steam reforming of ethanol at low temperature, and the $\mathrm{H}_{2}$ removal through the $\mathrm{Pd}_{77} \mathrm{Ag}_{23}$ membrane was very effective at achieving high $\mathrm{H}_{2}$ yield because of the kinetic inhibition of methane-forming reactions. To improve the membrane reactor performance, we developed the catalysts with addition of a trace amount $(\mathrm{M} / \mathrm{Co}=0.003(w / w))$ of precious metals such as $\mathrm{Ru}$ and Pd. Table 1 shows the performance of $\mathrm{Ru}-\mathrm{Co} / \mathrm{CeO}_{2}$ and $\mathrm{Pd}-\mathrm{Co} / \mathrm{CeO}_{2}$ in steam reforming of ethanol in the conventional and membrane reactors. It was interestingly found that the addition of a very small amount of Ru or Pd greatly enhanced the conversion of ethanol to $\mathrm{C}_{1}$ products. However, the $\mathrm{H}_{2}$ yield in the conventional reactor was not changed in $\mathrm{Ru}-\mathrm{Co} / \mathrm{CeO}_{2}$ and significantly decreased in $\mathrm{Pd}-\mathrm{Co} / \mathrm{CeO}_{2}$ compared to $\mathrm{Co} / \mathrm{CeO}_{2}$ (here, it should be noted that the $\mathrm{H}_{2}$ yield and conversion to $\mathrm{C}_{1}$ product on $\mathrm{Co} / \mathrm{CeO}_{2}$ was higher than those in Figure 2 even at the same reaction condition. This was owing to the refinement of flow system on the reactor in Figure S1). The low $\mathrm{H}_{2}$ yield can be explained by the thermodynamic equilibrium. The $\mathrm{C}_{1}$ selectivity at the thermodynamic equilibrium is $\mathrm{CO}_{2}: \mathrm{CO}: \mathrm{CH}_{4}=30.32: 0.15: 69.53$. Indeed, the methane selectivity approached the thermodynamic value with the increased conversion by the addition of $\mathrm{Ru}$ and $\mathrm{Pd}$, resulting in low $\mathrm{H}_{2}$ yield because produced $\mathrm{H}_{2}$ was consumed by reverse methane steam reforming from $\mathrm{CO}_{2}$ and $\mathrm{CO}$. In the membrane reactor, the $\mathrm{H}_{2}$ yield in both $\mathrm{Ru}-\mathrm{Co} / \mathrm{CeO}_{2}$ and $\mathrm{Pd}-\mathrm{Co} / \mathrm{CeO}_{2}$ was increased by the simultaneous $\mathrm{H}_{2}$ separation although the conversion was not changed. In addition, the methane selectivity was decreased by the $\mathrm{H}_{2}$ removal, and it was much lower than that at the thermodynamic equilibrium as shown in Table 1 . This indicates that the $\mathrm{H}_{2}$ removal by the $\mathrm{Pd}_{77} \mathrm{Ag}_{23}$ membrane kinetically inhibits the methane-forming reaction but does not shift the equilibrium as mentioned above. The platinum group is well-known to show high $\mathrm{H}_{2}$ dissociation/association ability and $\mathrm{H}_{2}$ spillover effect. Otsuka et al. reported that $\mathrm{Pt}$ accelerated the formation rates of $\mathrm{H}_{2}$ and $\mathrm{CO}$ in the partial oxidation of methane by the reverse spillover of $\mathrm{H}_{2}$ [32]. Lei et al. investigated the effect of $\mathrm{Rh}$ in the high temperature water-gas shift reaction, and they found that $\mathrm{Rh}$ greatly enhances $\mathrm{H}_{2}$ release during reoxidation by water, presumably by recombining hydrogen atoms transferred from oxide to metal by reverse spillover [33]. Therefore, the Ru and Pd might accelerate the association of hydrogen atom and desorption of $\mathrm{H}_{2}$ molecules from the catalyst through the reverse spillover mechanism. Comparing $\mathrm{Ru}-\mathrm{Co} / \mathrm{CeO}_{2}$ and $\mathrm{Pd}-\mathrm{Co} / \mathrm{CeO}_{2}, \mathrm{Ru}-\mathrm{Co} / \mathrm{CeO}_{2}$ exhibited high $\mathrm{H}_{2}$ yield and low methane selectivity. From the investigation in $\mathrm{C}_{1}$ selectivity with the conversions of ethanol as shown in Figure 4, the methane selectivity in $\mathrm{Pd}-\mathrm{Co} / \mathrm{CeO}_{2}$ was increased at lower conversions compared to $\mathrm{Ru}-\mathrm{Co} / \mathrm{CeO}_{2}$. This clearly indicates that the promotion effect of methane-forming reaction was higher in $\mathrm{Pd}$ than $\mathrm{Ru}$, probably caused by high $\mathrm{H}_{2}$ storage capacity of $\mathrm{Pd}$. Thus, the $\mathrm{Pd}$ membrane could effectively remove $\mathrm{H}_{2}$ through the reverse spillover on $\mathrm{Ru}$ before they reacted with $\mathrm{CO}_{2}$ or $\mathrm{CO}$ to methane, resulting in higher $\mathrm{H}_{2}$ yield in $\mathrm{Ru}-\mathrm{Co} / \mathrm{CeO}_{2}$. On the other hand, a certain part of hydrogen would react with $\mathrm{CO}_{2}$ and $\mathrm{CO}$ due to relatively high hydrogen concentration on $\mathrm{Pd}$ before desorption of $\mathrm{H}_{2}$ molecules by the reverse spillover mechanism, although the $\mathrm{Pd}_{77} \mathrm{Ag}_{23}$ membrane removed $\mathrm{H}_{2}$ from the reaction zone.

Table 1. Performance of conventional and membrane reactors over $\mathrm{Ru}-\mathrm{Co} / \mathrm{CeO}_{2}$ and $\mathrm{Pd}-\mathrm{Co} / \mathrm{CeO}$ in steam reforming of ethanol.

\begin{tabular}{ccccccc}
\hline \multirow{2}{*}{ Catalysts } & & \multirow{2}{*}{ Conversion to $\mathbf{C}_{\mathbf{1}}(\mathbf{\%})$} & \multirow{2}{*}{$\mathbf{H}_{\mathbf{2}}$ Yield (\%) } & \multicolumn{3}{c}{$\mathbf{C}_{\mathbf{1}}$ Selectivity (\%) } \\
\cline { 5 - 7 } & & & & $\mathbf{C O}_{\mathbf{2}}$ & $\mathbf{C O}$ & $\mathbf{C H}_{\mathbf{4}}$ \\
\hline $\mathrm{Co} / \mathrm{CeO}_{2}$ & $\mathrm{CR}$ & 63.4 & 47.6 & 70.3 & 6.0 & 23.6 \\
$\mathrm{Ru}-\mathrm{Co} / \mathrm{CeO}_{2}$ & $\mathrm{CR}$ & 86.8 & 42.3 & 59.0 & 3.3 & 37.7 \\
\multirow{2}{*}{$\mathrm{Pd}-\mathrm{Co} / \mathrm{CeO}_{2}$} & $\mathrm{MR}$ & 87.9 & 70.3 & 81.8 & 4.0 & 14.2 \\
& $\mathrm{MR}$ & 92.7 & 30.8 & 51.6 & 1.9 & 46.5 \\
& 94.2 & 52.9 & 65.3 & 2.4 & 32.3 \\
\hline
\end{tabular}

Reaction temperature: $623 \mathrm{~K}, \mathrm{~W} / \mathrm{F}: 1.0 \times 10^{4}$ g-cat min/C-mol. S/C = 2. Membrane: $\mathrm{Pd}_{77} \mathrm{Ag}_{23}$, Sweep Ar flow rate: $500 \mathrm{~mL} / \mathrm{min}$. CR: conventional reactor, MR: membrane reactor. 

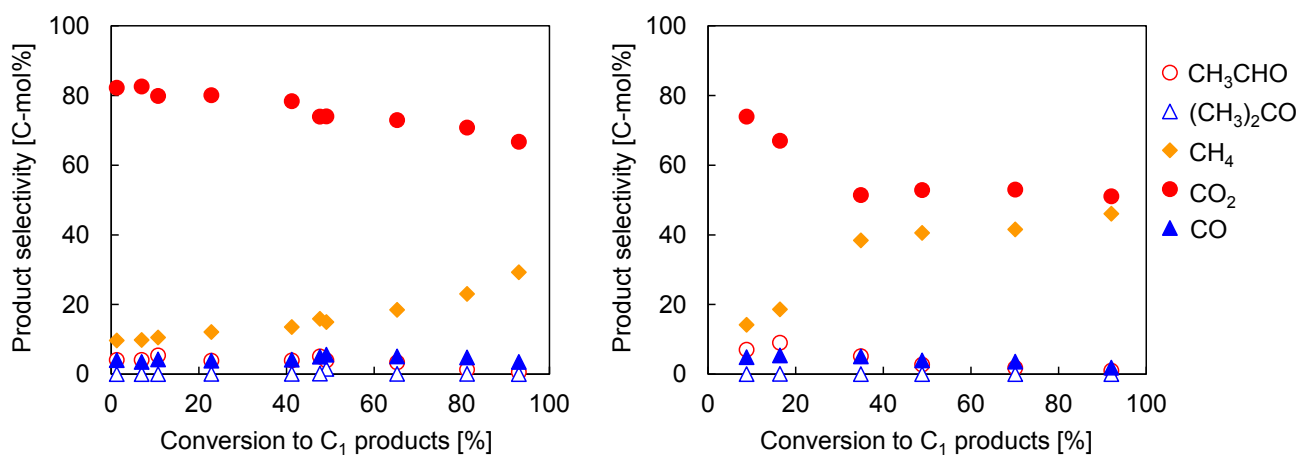

Figure 4. Product distribution over $\mathrm{Ru}-\mathrm{Co} / \mathrm{CeO}_{2}$ (left) and $\mathrm{Pd}-\mathrm{Co} / \mathrm{CeO}_{2}$ (right) in steam reforming of ethanol in conventional reactor. Reaction temperature: $623 \mathrm{~K}, S / C=2$.

\subsection{Comparison of Amorphous Alloy Membranes and $P d_{77} A g_{23}$ Membrane in the Membrane Reactor}

Figure 5 shows the $\mathrm{H}_{2}$ permeability of amorphous alloy membranes. The $\mathrm{H}_{2}$ permeability of $\mathrm{Ni}-\mathrm{Nb}-\mathrm{Zr}$ ternary alloy membrane was increased with increasing $\mathrm{Zr}$ content as the literature reported [34,35]. The $\mathrm{H}_{2}$ permeability of $\left(\mathrm{Ni}_{0.6} \mathrm{Nb}_{0.4}\right)_{70} \mathrm{Zr}_{30}$ was approximately $8.8 \times 10^{-9} \mathrm{~mol} \cdot \mathrm{m}^{-1} \cdot \mathrm{s}^{-1} \cdot \mathrm{Pa}^{-0.5}$, which is consistent with the value reported by the researchers [36]. Paglieri et al. reported that the addition of Ta lowered the $\mathrm{H}_{2}$ permeability, although this slightly improves the thermal stability [37]. We have found that the increase in Ta content slightly decreased the $\mathrm{H}_{2}$ permeability of $\mathrm{Ni}-\mathrm{Nb}-\mathrm{Ta}-\mathrm{Zr}$ quaternary alloy membranes [38]. Indeed, Ni-Ta-Zr ternary alloy membranes showed the lower $\mathrm{H}_{2}$ permeability in our study as well. In contrast, the addition of a small amount of $\mathrm{Zr}$ and $\mathrm{Ta}$ increased the $\mathrm{H}_{2}$ permeability in $\mathrm{Nb}-\mathrm{Ni}$-Co alloy membranes because the introduction of larger atoms expanded the amorphous structure, resulting in an increase in $\mathrm{H}_{2}$ diffusivity [39]. Thus, the $\mathrm{Ni}_{40} \mathrm{Nb}_{20} \mathrm{Ta}_{5} \mathrm{Zr}_{30} \mathrm{Co}_{5}$ alloy membrane exhibited the highest $\mathrm{H}_{2}$ permeability that was comparable to the $\mathrm{Pd}_{77} \mathrm{Ag}_{23}$ membrane.

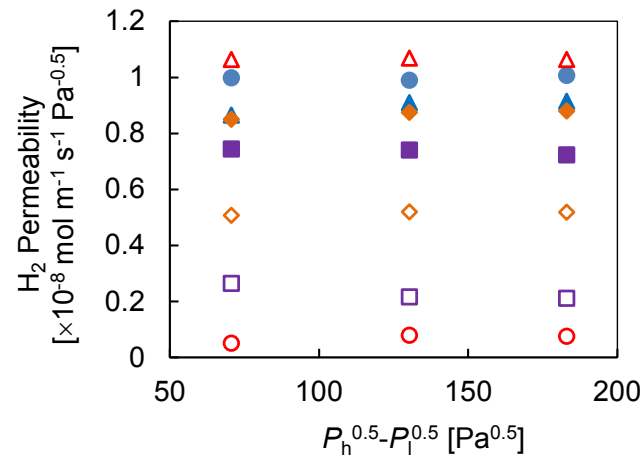

$\mathrm{Pd}_{77} \mathrm{Ag}_{23}$

$\triangle\left(\mathrm{Ni}_{0.5} \mathrm{Nb}_{0.5}\right)_{80} \mathrm{Zr}_{20}$

$\diamond\left(\mathrm{Ni}_{0.6} \mathrm{Nb}_{0.4}\right)_{80} \mathrm{Zr}_{20}$

$\diamond\left(\mathrm{Ni}_{0.6} \mathrm{Nb}_{0.4}\right)_{70} \mathrm{Zr}_{30}$

$\square\left(\mathrm{Ni}_{0.67} \mathrm{Ta}_{0.33}\right)_{80} \mathrm{Zr}_{20}$

- $\left(\mathrm{Ni}_{0.67} \mathrm{Ta}_{0.33}\right)_{70} \mathrm{Zr}_{20}$

$\triangle \mathrm{Ni}_{40} \mathrm{Nb}_{20} \mathrm{Ta}_{5} \mathrm{Zr}_{20} \mathrm{Co}_{5}$

O $\mathrm{Pd}_{78} \mathrm{Cu}_{6} \mathrm{Si}_{16}$

Figure 5. $\mathrm{H}_{2}$ permeability of amorphous alloy membranes at $623 \mathrm{~K} . P_{\mathrm{h}}=0.15,0.20$ and $0.25 \mathrm{MPa}$.

The steam reforming of ethanol over $\mathrm{Ru}-\mathrm{Co} / \mathrm{CeO}_{2}$ was evaluated in the membrane reactors with amorphous alloy membranes. Table 2 summarizes the membrane reactor performance. $\mathrm{The}_{2}$ yield was clearly related to $\mathrm{H}_{2}$ removal ratio. Indeed, the amorphous membranes with the lowest $\mathrm{H}_{2}$ removal ratio of approximately $10 \%$, such as $\left(\mathrm{Ni}_{0.67} \mathrm{Ta}_{0.33}\right)_{80} \mathrm{Zr}_{20}$ and $\mathrm{Pd}_{78} \mathrm{Cu}_{6} \mathrm{Si}_{16}$, exhibited the same membrane reactor performance, and a similar $\mathrm{H}_{2}$ yield was obtained on the $\left(\mathrm{Ni}_{0.6} \mathrm{Nb}_{0.4}\right)_{70} \mathrm{Zr}_{30}$ and $\mathrm{Ni}_{40} \mathrm{Nb}_{20} \mathrm{Ta}_{5} \mathrm{Zr}_{30} \mathrm{Co}_{5}$ with the highest $\mathrm{H}_{2}$ removal ratio of approximately $50 \%$. However, the $\mathrm{H}_{2}$ removal ratio was not the same order of the $\mathrm{H}_{2}$ permeability. For example, the $\mathrm{H}_{2}$ yield and $\mathrm{H}_{2}$ removal ratio in the $\left(\mathrm{Ni}_{0.6} \mathrm{Nb}_{0.4}\right)_{70} \mathrm{Zr}_{30}$ membrane was higher than that in the $\left(\mathrm{Ni}_{0.5} \mathrm{Nb}_{0.5}\right)_{80} \mathrm{Zr}_{20}$ and was almost comparable to $\mathrm{Ni}_{40} \mathrm{Nb}_{20} \mathrm{Ta}_{5} \mathrm{Zr}_{30} \mathrm{Co}_{5}$, although the $\mathrm{H}_{2}$ permeability was on the order of 
$\mathrm{Ni}_{40} \mathrm{Nb}_{20} \mathrm{Ta}_{5} \mathrm{Zr}_{30} \mathrm{Co}_{5}>\left(\mathrm{Ni}_{0.5} \mathrm{Nb}_{0.5}\right)_{80} \mathrm{Zr}_{20} \cong\left(\mathrm{Ni}_{0.6} \mathrm{Nb}_{0.4}\right)_{70} \mathrm{Zr}_{30}$. This could be owing to their membrane thickness that is in inverse proportion to the $\mathrm{H}_{2}$ permeation flux when the membrane is thick enough.

Table 2. Comparison of the membrane reactor performance using amorphous alloy membranes and $\mathrm{Pd}_{77} \mathrm{Ag}_{23}$ membrane in the steam reforming of ethanol.

\begin{tabular}{|c|c|c|c|c|c|c|}
\hline \multirow{2}{*}{ Membrane } & \multirow{2}{*}{$\begin{array}{c}\text { Membrane } \\
\text { Thickness }(\mu \mathrm{m})\end{array}$} & \multirow[b]{2}{*}{$\mathrm{H}_{2}$ removal (\%) } & \multirow[b]{2}{*}{$\mathrm{H}_{2}$ Yield (\%) } & \multicolumn{3}{|c|}{$\mathrm{C}_{1}$ Selectivity (\%) } \\
\hline & & & & $\mathrm{CO}_{2}$ & $\mathrm{CO}$ & $\mathrm{CH}_{4}$ \\
\hline$\left(\mathrm{Ni}_{0.5} \mathrm{Nb}_{0.5}\right)_{80} \mathrm{Zr}_{20}$ & 41.6 & 40.0 & 58.1 & 72.9 & 3.7 & 23.4 \\
\hline$\left(\mathrm{Ni}_{0.6} \mathrm{Nb}_{0.4}\right)_{70} \mathrm{Zr}_{30}$ & 27.7 & 49.2 & 65.6 & 75.8 & 2.8 & 21.4 \\
\hline$\left(\mathrm{Ni}_{0.67} \mathrm{Ta}_{0.33}\right)_{80} \mathrm{Zr}_{20}$ & 35.7 & 10.0 & 47.9 & 66.3 & 5.1 & 29.0 \\
\hline$\left(\mathrm{Ni}_{0.67} \mathrm{Ta}_{0.33}\right)_{70} \mathrm{Zr}_{30}$ & 38.7 & 36.6 & 55.7 & 69.3 & 5.2 & 25.5 \\
\hline $\mathrm{Pd}_{77} \mathrm{Ag}_{23}$ & 20.0 & 58.0 & 70.3 & 81.8 & 4.0 & 14.2 \\
\hline
\end{tabular}

Catalyst: $\mathrm{Ru}-\mathrm{Co} / \mathrm{CeO}_{2}$, reaction temperature: $623 \mathrm{~K}, 1.0 \times 10^{4}$ g-cat min/C-mol. $\mathrm{S} / \mathrm{C}=2$, sweep Ar flow rate: $500 \mathrm{~mL} / \mathrm{min}$.

Finally, we carried out the steam reforming of ethanol in the $\operatorname{Pd}_{77} \mathrm{Ag}_{23}$ membrane reactor with different sweep Ar flow rate to understand the effect of $\mathrm{H}_{2}$ removal by the membrane on $\mathrm{H}_{2}$ yield. Figure 6 shows the $\mathrm{H}_{2}$ yield and $\mathrm{C}_{1}$ selectivity as a function of $\mathrm{H}_{2}$ removal ratio. The solid lines were interpolated from the experimental results on the $\mathrm{Pd}_{77} \mathrm{Ag}_{23}$ membrane reactor by varying the sweep Ar flow rate to obtain different $\mathrm{H}_{2}$ removal ratio. Interestingly, the $\mathrm{H}_{2}$ yield and $\mathrm{C}_{1}$ selectivity in the amorphous membranes fitted the curve well. This clearly shows that the membrane reactor performance was determined by the $\mathrm{H}_{2}$ removal ratio. Considering the reaction mechanism mentioned in Section 3.1, at the low reaction temperature, the catalytic performance such as $\mathrm{C}_{1}$ selectivity was kinetically controlled by the $\mathrm{H}_{2}$ permeation rate through the membrane. Thus, it is not an unexpected result that the membrane reactor performance using different amorphous membranes fitted those with the $\mathrm{Pd}_{77} \mathrm{Ag}_{23}$ membrane. In other words, we can roughly predict the membrane reactor performance based on their actual $\mathrm{H}_{2}$ permeation flux regardless of the metal composition of the alloy membranes. Indeed, the $\mathrm{H}_{2}$ removal ratio is clearly related to the $\mathrm{H}_{2}$ permeation flux of the membrane as shown in Figure 7.
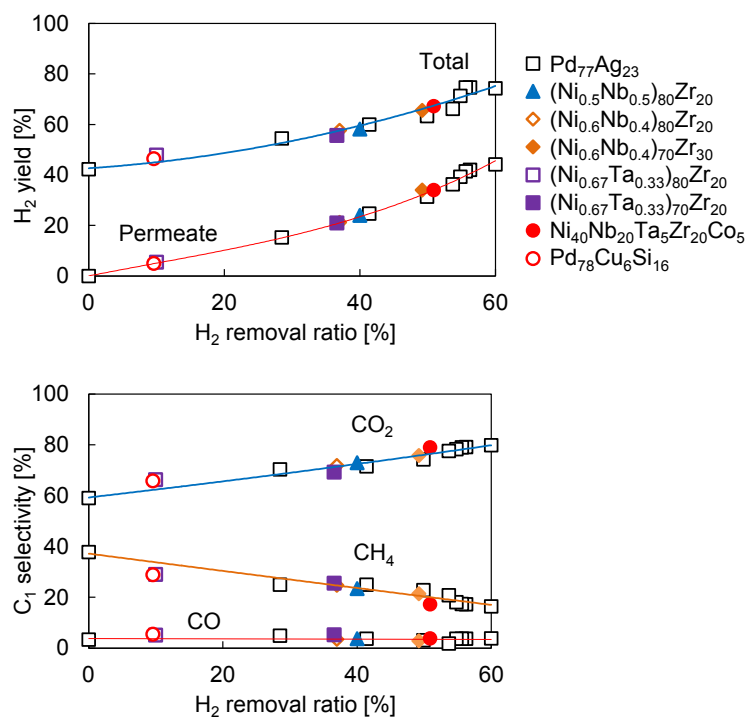

Figure 6. $\mathrm{H}_{2}$ yield and $\mathrm{C}_{1}$ selectivity in the membrane reactors using $\mathrm{Pd}_{77} \mathrm{Ag}_{23}$ and amorphous alloy membranes in steam reforming of ethanol at $623 \mathrm{~K}$. Catalyst: $\mathrm{Ru}-\mathrm{Co} / \mathrm{CeO}_{2}, 1.0 \times 10^{4} \mathrm{~g}$-cat min/C-mol. $S / C=2$. 


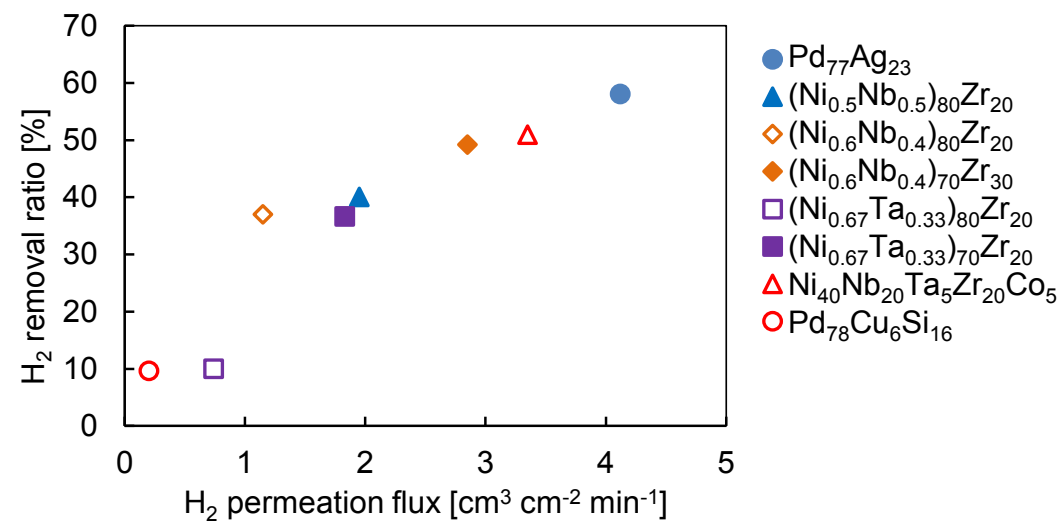

Figure 7. $\mathrm{H}_{2}$ removal ratio as a function of $\mathrm{H}_{2}$ permeation flux in the amorphous alloy membranes and $\mathrm{Pd}_{77} \mathrm{Ag}_{23}$ membrane at $623 \mathrm{~K}$ and $0.05 \mathrm{MPa}-\mathrm{G}$ in the feed side.

\section{Conclusions}

We evaluated the Pd membrane performance over $\mathrm{Ni} / \mathrm{CeO}_{2}$ and $\mathrm{Co} / \mathrm{CeO}_{2}$ in steam reforming of ethanol. In the conventional fixed bed reactor, $\mathrm{Ni} / \mathrm{CeO}_{2}$ showed low $\mathrm{H}_{2}$ yield compared to $\mathrm{Co} / \mathrm{CeO}_{2}$ although the conversion to $\mathrm{C}_{1}$ products was much higher at the temperatures. In the membrane reactor, the simultaneous $\mathrm{H}_{2}$ separation improved both conversion of ethanol to $\mathrm{C}_{1}$ products and $\mathrm{H}_{2}$ yield. For $\mathrm{Ni} / \mathrm{CeO}_{2}$, the $\mathrm{H}_{2}$ yield exceeded that in $\mathrm{Co} / \mathrm{CeO}_{2}$ at $773 \mathrm{~K}$. However, at $673 \mathrm{~K}$, although $\mathrm{H}_{2}$ yield over $\mathrm{Ni} / \mathrm{CeO}_{2}$ was slightly increased by $\mathrm{H}_{2}$ removal, it was lower than that over $\mathrm{Co} / \mathrm{CeO}_{2}$. The difference of the $\mathrm{H}_{2}$ removal effect in those catalysts could be due to their reaction mechanism. At high reaction temperature, the higher the reaction rate of steam reforming of ethanol in $\mathrm{Ni} / \mathrm{CeO}_{2}$ compared to $\mathrm{Co} / \mathrm{CeO}_{2}$, the higher the increase rate of $\mathrm{H}_{2}$ yield that was achieved due to the higher equilibrium shift effect by $\mathrm{H}_{2}$ removal. However, at low reaction temperature, the methane-forming reaction in $\mathrm{Ni} / \mathrm{CeO}_{2}$ inhibits the $\mathrm{H}_{2}$ permeation, resulting in a low $\mathrm{H}_{2}$ yield. From these results, the $\mathrm{H}_{2}$ separation membrane can improve the $\mathrm{H}_{2}$ yield thermodynamically at high reaction temperature, but the simultaneous $\mathrm{H}_{2}$ separation kinetically inhibited methane formation by $\mathrm{H}_{2}$ removal at a low reaction temperature.

The amorphous alloy membranes with different compositions were employed in the steam reforming of ethanol, and the membrane reactor performance was compared with the $\mathrm{Pd}_{77} \mathrm{Ag}_{23}$ membrane. Regardless of membrane composition, the membrane reactor performance could be set in the order of $\mathrm{H}_{2}$ permeation flux.

Acknowledgments: This work was performed under the inter-university cooperative research program(Proposal No. 10G0045) of the Advanced Research Center of Metallic Glasses, Institute for materials Research, Tohoku University

Author Contributions: M.M. and S.U. conceived and designed the experiments; Y.Y. performed the experiments and analyzed the data; Y.O. contributed analysis tools; S.Y. provided the amorphous membranes; M.M. wrote the paper.

Conflicts of Interest: The authors declare no conflict of interest.

\section{References}

1. Holladay, J.D.; Hu, J.; King, D.L.; Wang, Y. An overview of hydrogen production technologies. Catal. Today 2009, 139, 244-260. [CrossRef]

2. Zou, X.; Wang, X.; Li, L.; Shen, K.; Lu, X.; Ding, W. Development of highly effective supported nickel catalysts for pre-reforming of liquefied petroleum gas under low steam to carbon molar ratios. Int. J. Hydrogen Energy 2010, 35, 12191-12200. [CrossRef]

3. Laosiripojana, N.; Assabumrungrat, S. Hydrogen production from steam and autothermal reforming of LPG over high surface area ceria. J. Power Sources 2006, 158, 1348-1357. [CrossRef] 
4. Lu, Y.; Chen, J.; Liu, Y.; Xue, Q.; He, M. Highly sulfur-tolerant Pt $/ \mathrm{Ce}_{0.8} \mathrm{Gd}_{0.2} \mathrm{O}_{1.9}$ catalyst for steam reforming of liquid hydrocarbons in fuel cell applications. J. Catal. 2008, 254, 39-48. [CrossRef]

5. Suzuki, T.; Iwanami, H.; Yoshinari, T. Steam reforming of kerosene on $\mathrm{Ru} / \mathrm{Al}_{2} \mathrm{O}_{3}$ catalyst to yield hydrogen. Int. J. Hydrogen Energy 2000, 25, 119-126. [CrossRef]

6. Yu, X.H.; Zhang, S.C.; Wang, L.Q.; Jiang, Q.; Li, S.G.; Tao, Z. Hydrogen production from steam reforming of kerosene over Ni-La and Ni-La-K/cordierite catalysts. Fuel 2006, 85, 1708-1713. [CrossRef]

7. Muramoto, T.; Nariai, K.; Ohara, H.; Kamata, H. Durability of $\mathrm{Ru} / \mathrm{CeO}_{2} / \gamma-\mathrm{Al}_{2} \mathrm{O}_{3}$ catalyst for steam reforming of dodecane. J. Jpn. Petrol. Inst. 2009, 52, 108-113. [CrossRef]

8. Miyamoto, M.; Arakawa, M.; Oumi, Y.; Uemiya, S. Influence of metal cation doping on $\mathrm{Ru} / \mathrm{CeO}_{2} / \mathrm{Al}_{2} \mathrm{O}_{3}$ catalyst for steam reforming of desulfurized kerosene. Int. J. Hydrogen Energy 2015, 40, 2657-2662. [CrossRef]

9. Murdoch, M.; Waterhouse, G.I.N.; Nadeem, M.A.; Metson, J.B.; Keane, M.A.; Howe, R.F.; Llorca, J.; Idriss, H. The effect of gold loading and particle size on photocatalytic hydrogen production from ethanol over $\mathrm{Au} / \mathrm{TiO}_{2}$ nanoparticles. Nat. Chem. 2011, 3, 489-492. [CrossRef] [PubMed]

10. Meng, N.; Leung, D.Y.C.; Leung, M.K.H. A review on reforming bio-ethanol for hydrogen production. Int. J. Hydrogen Energy 2007, 32, 3238-3247.

11. Vaidya, P.D.; Rodrigues, A.E. Insight into steam reforming of ethanol to produce hydrogen for fuel cells. Chem. Eng. J. 2006, 117, 39-49. [CrossRef]

12. Haryanto, A.; Fernando, S.; Murali, N.; Adhikari, S. Current status of hydrogen production techniques by steam reforming of ethanol: A Review. Energy \& Fuel 2005, 19, 2098-2106.

13. Deluga, G.A.; Salge, J.R.; Schmidt, L.D.; Verykios, X.E. Renewable hydrogen from ethanol by autothermal reforming. Science 2004, 303, 993-997. [CrossRef] [PubMed]

14. Frusteri, F.; Freni, S. Bio-ethanol, a suitable fuel to produce hydrogen for a molten carbonate fuel cell. J. Power Source 2007, 173, 200-209. [CrossRef]

15. Idriss, H.; Scott, M.; Llorca, J.; Chan, S.C.; Chiu, W.; Sheng, P.-Y.; Yee, A.; Blackford, M.A.; Pas, S.J.; Hill, A.J.; et al. A Phenomenological study of the metal-oxide interface: The role of catalysis in hydrogen production from renewable resources. ChemSusChem 2008, 1, 905-910. [CrossRef] [PubMed]

16. Torres, J.A.; Llorca, J.; Casanovas, A.; Domínguez, M.; Salvadó, J.; Montané, D. Steam reforming of ethanol at moderate temperature: Multifactorial design analysis of $\mathrm{Ni} / \mathrm{La}_{2} \mathrm{O}_{3}-\mathrm{Al}_{2} \mathrm{O}_{3}$ and $\mathrm{Fe}$ - and $\mathrm{Mn}$-promoted $\mathrm{Co} / \mathrm{ZnO}$ catalysts. J. Power Source 2007, 169, 158-166. [CrossRef]

17. Sun, J.; Qiu, X.-P.; Wu, F.; Zhu, W.-T. $\mathrm{H}_{2}$ from steam reforming of ethanol at low temperature over $\mathrm{Ni} / \mathrm{Y}_{2} \mathrm{O}_{3}$, $\mathrm{Ni} / \mathrm{La}_{2} \mathrm{O}_{3}$ and $\mathrm{Ni} / \mathrm{Al}_{2} \mathrm{O}_{3}$ catalysts for fuel-cell application. Int. J. Hydrogen Energy 2005, 30, 437-445. [CrossRef]

18. Comas, J.; Mariño, F.; Laborde, M.; Amadeo, N. Bio-ethanol steam reforming on $\mathrm{Ni} / \mathrm{Al}_{2} \mathrm{O}_{3}$ catalyst. Chem. Eng. J. 2004, 98, 61-68. [CrossRef]

19. Casanovas, A.; de Leitenburg, C.; Trovarelli, A.; Llorca, J. Catalytic monoliths for ethanol steam reforming. Catal. Today 2008, 138, 187-192. [CrossRef]

20. Rikukawa, M.; Sanui, K. Proton-conducting polymer electrolyte membranes based on hydrocarbon polymers. Prog. Polym. Sci. 2000, 25, 1463-1502. [CrossRef]

21. Neburchilov, V.; Martin, J.; Wang, H.; Zhang, J. A review of polymer electrolyte membranes for direct methanol fuel cells. J. Power Sources 2007, 169, 221-238. [CrossRef]

22. Rakib, M.A.; Grace, J.R.; Lim, C.J.; Elnashaie, S.S.E.H.; Ghiasi, B. Steam reforming of propane in a fluidized bed membrane reactor for hydrogen production. Int. J. Hydrogen Energy 2010, 35, 6276-6290. [CrossRef]

23. Perna, A.; Cicconardi, S.P.; Cozzolino, R. Performance evaluation of a fuel processing system based on membrane reactors technology integrated with a PMFC stack. Int. J. Hydrogen Energy 2011, 36, 9906-9915. [CrossRef]

24. Miyamoto, M.; Hayakawa, C.; Kamata, K.; Arakawa, M.; Uemiya, S. Influence of the pre-reformer in steam reforming of dodecane using a Pd alloy membrane reactor. Int. J. Hydrogen Energy 2011, 36, 7771-7775. [CrossRef]

25. Iulianelli, A.; Basile, A. An experimental study on bio-ethanol steam reforming in a catalytic membrane reactor. Part I: Temperature and sweep-gas flow configuration effects. Int. J. Hydrogen Energy 2010, 35, 3170-3177. [CrossRef] 
26. Iulianelli, A.; Liguori, S.; Longo, T.; Tosti, S.; Pinacci, P.; Basile, A. An experimental study on bio-ethanol steam reforming in a catalytic membrane reactor. Part II: Reaction pressure, sweep factor and WHSV effects. Int. J. Hydrogen Energy 2010, 35, 3159-3164. [CrossRef]

27. Seelam, P.K.; Liguori, S.; Iulianelli, A.; Pinacci, P.; Calabrò, V.; Huuhtanen, M.; Keiski, R.; Piemonte, V.; Tosti, S.; De Falco, M.; et al. Hydrogen production from bio-ethanol steam reforming reaction in a Pd/PSS membrane reactor. Catal. Today 2012, 193, 42-48. [CrossRef]

28. Domínguez, M.; Taboada, E.; Molins, E.; Llorca, J. Ethanol steam reforming at very low temperature over cobalt talc in a membrane reactor. Catal. Today 2012, 139, 101-106. [CrossRef]

29. Espinal, R.; Anzola, A.; Adrover, E.; Roig, M.; Chimentao, R.; Medina, F.; López, E.; Borio, D.; Llorca, J. Durable ethanol steam reforming in a catalyticmembrane reactor at moderate temperature over cobalt hydrotalcite. Int. J. Hydrogen Energy 2014, 39, 10902-10910. [CrossRef]

30. Lim, H.; Gu, Y.; Oyama, S.T. Studies of the effect of pressure and hydrogen permeance on the ethanol steam reforming reaction with palladium- and silica-based membranes. J. Membr. Sci. 2012, 396, 119-127. [CrossRef]

31. Zhang, B.; Tang, X.; Li, Y.; Xu, Y.; Shen, W. Hydrogen production from steam reforming of ethanol and glycerol over ceria-supported metal catalysts. Int. J. Hydrogen Energy 2007, 32, 2367-2373. [CrossRef]

32. Otsuka, K.; Wang, Y.; Sunada, E.; Yamanaka, I. Direct partial oxidation of methane to synthesis gas by cerium oxide. J. Catal. 1998, 175, 152-160. [CrossRef]

33. Lei, Y.; Cant, N.W.; Trimm, D.L. The origin of rhodium promotion of $\mathrm{Fe}_{3} \mathrm{O}_{4}-\mathrm{Cr}_{2} \mathrm{O}_{3}$ catalysts for the high-temperature water-gas shift reaction. J. Catal. 2006, 239, 227-236. [CrossRef]

34. Yamaura, S.; Sakurai, M.; Hasegawa, M.; Wakoh, K.; Shimpo, Y.; Nishida, M.; Kimura, H.; Matsubara, E.; Inoue, A. Hydrogen permeation and structural features of melt-spun $\mathrm{Ni}-\mathrm{Nb}-\mathrm{Zr}$ amorphous alloys. Acta Mater. 2005, 53, 3703-3711. [CrossRef]

35. Yamaura, S.; Shimpo, Y.; Okouchi, H.; Nishida, M.; Kajita, O.; Kimura, H.; Inoue, A. Hydrogen permeation characteristics of melt-spun $\mathrm{Ni}-\mathrm{Nb}-\mathrm{Zr}$ amorphous alloy membranes. Matar. Trans. 2003, 44, 1885-1890. [CrossRef]

36. Kim, S.-M.; Chandra, D.; Pal, N.K.; Dolan, M.D.; Chien, W.-M.; Talekar, A.; Lamb, J.; Paglieri, S.N.; Flanagan, T.B. Hydrogen permeability and crystallization kinetics in amorphous $\mathrm{Ni}-\mathrm{Nb}-\mathrm{Zr}$ alloys. Int. J. Hydrogen Energy 2012, 37, 3904-3913. [CrossRef]

37. Paglieri, S.N.; Pal, N.K.; Dolan, M.D.; Kim, S.-M.; Chien, W.-M.; Lamb, J.; Chandra, D.; Hubbard, K.M.; Moore, D.P. Hydrogen permeability, thermal stability and hydrogen embrittlement of $\mathrm{Ni}-\mathrm{Nb}-\mathrm{Zr}$ and $\mathrm{Ni}-\mathrm{Nb}-\mathrm{Ta}-\mathrm{Zr}$ amorphous alloy membranes. J. Membr. Sci. 2011, 378, 42-50. [CrossRef]

38. Qiang, J.B.; Zhang, W.; Yamaura, S.; Inoue, A. Thermal stability and hydrogen permeation of $\mathrm{Ni}_{42} \mathrm{Zr}_{30} \mathrm{Nb}_{28} x \mathrm{Ta} x$ amorphous alloys. Matar. Trans. 2009, 50, 1236-1239. [CrossRef]

39. Ding, H.Y.; Zhang, W.; Yamaura, S.; Yao, K.F. Hydrogen permeable Nb-based amorphous alloys with high thermal stability. Mater. Trans. 2013, 54, 1330-1334. [CrossRef]

(C) 2016 by the authors; licensee MDPI, Basel, Switzerland. This article is an open access article distributed under the terms and conditions of the Creative Commons Attribution (CC-BY) license (http://creativecommons.org/licenses/by/4.0/). 